will be necessary to interpret the usefulness of new infection control interventions.

\section{REFERENCES}

1. Tuberculosis in New York City, 1992. New York City, NY: Bureau of Tuberculosis Control, Department of Health information summary; 1993.

2. Sepkowitz KA. Tuberculosis and the health care worker: a historical perspective. Ann Intern Med 1994;120:71-79.

3. Centers for Disease Control and Prevention. Expanded tuberculosis surveillance and tuberculosis morbidity-United States, 1993. MMWR 1994;43:361-366.

4. Centers for Disease Control and Prevention. Guidelines for preventing the transmission of Mycobacterium tuberculosis in health-care facilities, 1994. $M M W R$ 1994;43(RR-13):1-132.

5. Bowden KM, McDiarmid MA. Occupationally acquired tuberculosis: what's known. J Occup Med 1994;36:320-325.

6. Sepkowitz KA. AIDS, tuberculosis. and the health care worker. Clin Infect Dis 1995;20:232-242.

7. Menzies R, Vissandjee B, Rocher I, St Germain Y. The booster effect in two-step tuberculin testing among young adults in Montreal. Ann Intern
Med 1994;120:190-198.

8. Rosenblum IS, Castro KG, Dooley S, Morgan M. Effect of HIV infection and tuberculosis on hospitalizations and cost of care for young adults in the United States, 19851990. Ann Intern Med 1994;121:786-792.

9. Reichman LB, O'Day R. Tuberculosis screening in a large urban population.AmRev RespirDis 1978;117:705-712.

10. Cross ER, Hyams KC. Tuberculin skin testing in US Navy and Marine Corps personnel and recruits, 1980-1986. Am J Public Health 1990;80:435438.

11. Fraser VJ, Kilo CM, Bailey TC, Medoff G, Dunagan WC. Screening of physicians for tuberculosis. Infect Control Hosp Epidemiol 1994;15:9 100.

12. Schwartzman $\mathrm{K}$, Loo V, Menzies R Prevalence of tuberculous infection in healthcare workers. Am J Respir Crit Care Med 1994; A853.

13. Stracher AR, Fuentes LS, Ramos E, Stoeckle MY, Sepkowitz KA. High prevalence of baseline PPD positivity in healthcare workers at a New York City hospital.Clin Res 1994;42:302A.Abstract.

14. Lanphear BP, Linnemann CC, Cannon CG. A high false-positive rate of tuberculosis associated with Aplisol: an investigation among health care workers. J Infect Dis 1994;169:703-704.

\title{
Newly Identified Virus Kills Trainer and 14 Horses in Australia
}

\section{by Gina Pugliese, RN, MS Medical News Editor}

In what is believed to be the quickest discovery in veterinary medicine, scientists have identified a new virus just 12 days after an outbreak in Brisbane, Australia, killed a trainer and 14 horses. The virus, which has not been named, belongs to the morbilliform family, which includes the measles virus. It is believed to be the first new virus in the family to attack humans since the measles virus. It leaps from animal to human, where it proved fatal in the first case detected. It causes an illness that includes high fever, interstitial pneumonia, and severe damage to the blood vessels.
Government scientists were called in to identify the virus after it had killed a few horses and infected two humans. One of the humans, a 49-year-old horse trainer, died from complications of interstitial pneumonia after 6 days. The second, a 40-yearold stable hand who helped care for a dying mare, developed a severe influenza-like illness but recovered. During the investigation, the scientists ruled out the recently discovered Hanta strain, anthrax, and poisoning. Tissue cultures began showing evidence of viral growth, and examination of the growth using electron microscopy revealed the herringbone structure characteristic of the morbilliform virus. Up to this time, no member of this family of viruses had caused disease in both horses and humans. The virus was identified in the lungs of four of the dead horses and in none of the healthy horses. After injecting tissue from the sick horses into two healthy horses, they became agitated and developed severe respiratory illness. The same virus also was isolated from the kidneys of the trainer.

The morbilliform group of viruses includes the canine distemper, seal plague, and rinderpest viruses in addition to the measles virus.

FROM: Altman L. Deadly disease attributed to new virus. New York Times April 7, 1995, p A9. 